Asy Syar'iyyah: Jurnal Ilmu Syari'ab dan Perbankan Islam - ISSN 2089-7227 (p) 2598-8522 (e)

Vol. 3, No. 1, Juni 2018, pp.1 - 25

\title{
STATUS HUKUM KHAMAR DALAM PERSFEKTIF FIQH
}

\author{
Winarno \\ IAIN Syaikh Abdurrahman Siddik Bangka Belitung
}

\begin{abstract}
The verse that talks about the prohibition of drinking khamar in the Alqur'an was gradually reduced in the midst of the ignorant Arab community who had the habit of drinking khamar, getting drunk and to change such conditions in a gradual manner. First, khamar and gambling contain major sins eventhough they contain benefits for humans, but the harm is greater than the benefits. Secondly, it was stated that they were not allowed to pray drunk Third, it is expressly stated that khamar is one of Devil's actions and therefore must be shunned.

The scholars differed in defining this khamar. According to Imam Malik, Shafi'i and Ahmad what is meant by khamar is intoxicating drinks, whether or not called khamar. According to Imam Abu Hanifah, it was different from the drunken Khamar drink. But regardless of the definition of the substance is the same, that everything that is intoxicating is a little or a lot of things that are still forbidden.

Thus it can be concluded that the prohibition of the khamar does not lie in drunkenness or not, but the location of the substance on the substance. In other words, drinking khamar even if it does not intoxicate the law remains unclean.
\end{abstract}

Keywords: Khamar, Intoxicating, Prohibition.

\section{A. Pendahuluan}

Syariat Islam mengharamkan khamar sejak empat belas abad yang lalu dan hal ini berkaitan dengan penghargaan Islam terhadap akal manusia yang merupakan anugerah dari Allah Swt. yang harus dipelihara sebaik-baiknya dan sekarang mulai orang non muslim menyadari akan manfaat diharamkannya khamar setelah terbukti bahwa khamar dan sebagainya (penyalahgunaan narkotika, ganja, morpin, ekstasi dan lain sebagainya) membawa mudharat bagi bangsa.

Al-Qur'an diturunkan di tengah-tengah masyarakat Arab jahiliyah yang memiliki kebiasaan minum khamar, mabuk-mabukan dan untuk mengubah 
kondisi yang demikian ditempuh dengan cara al-tadrij (bertahap). ${ }^{1}$ Pertama, khamar dan maisir (judi) mengandung dosa besar meskipun mengandung manfaat bagi manusia, akan tetapi mudharatnya lebih besar daripada manfaatnya. Kedua, dinyatakan tidak boleh melaksanakan shalat dalam keadaan mabuk. Ketiga, tegas-tegas dinyatakan bahwa khamar itu salah satu perbuatan setan dan karenanya harus dijauhi.

Para fuqaha berbeda pendapat dalam mendefenisikan khamar ini. Menurut imam Malik, Syafi'i dan Ahmad yang dimaksud dengan khamar itu adalah minuman-minuman yang memabukkan, baik disebut khamar maupun tidak. Menurut imam Abu Hanifah berbeda dengan minuman khamar dengan mabuk. Beliau mengharamkan minum khamar baik sedikit maupun banyak. Adapun minuman lain yang memabukkan dan bukan khamar menurut beliau disebut sebagai minuman yang memabukkan. Menurutnya minuman yang memabukkan selain khamar keharamannya bukan lidzatihi maka yang haram adalah minum terakhir yang membawa dampak pada mabuk.

\section{B. Pengertian Khamar}

Khamar adalah cairan yang dihasilkan dari peragian biji-bijian atau buah-buahan dan mengubah saripatinya menjadi alkohol dengan menggunakan katalisator (enzim) yang mempunyai kemampuan untuk memisahkan unsur-unsur tertentu yang berubah melalui proses peragian. ${ }^{2}$ Sehingga minuman sejenis ini dinamakan khamar karena ia mengeruhkan dan menyelubungi akal. Artinya menutupi dan merusak daya tangkapnya. Beginilah pengertian khamar menurut kedokteran. ${ }^{3}$

1 M. Ali Al-Shabuni (a), Terjemahan Tafsir Ayat Ahkam, Diterjemahkan Oleh: Mu'ammal Hamidy dan Imron Al-Manan, (Surabaya: PT. Bina Ilmu, 2003), hlm. 217-218.

2 Sayyid Sabiq, Fiqh Sunnah Jilid III, Alih Bahasa: Nor Hasanuddin, (Jakarta: Pena Pundi Aksara, 2004), hlm. 276

3 Dadang Hawari, Penyalahgunaan Narkotika dan Zat Adiktif, (Jakarta: Balai Penerbit Fakultas Kedokteran Indonesia, 1991) hlm. 91 
Setiap sesuatu yang memabukkan adalah termasuk khamar dan tidak menjadi soal tentang apa asalnya. Oleh karena itu, jenis minuman apa pun sejauh memabukkan adalah khamar menurut pengertian syariat dan hukumhukum yang berlaku terhadap khamar adalah juga berlaku atas minumanminuman tersebut, baik ia terbuat dari anggur, kurma, madu, gandum dan bijibijian lain maupun dari jenis-jenis lain. Semuanya termasuk khamar dan haram hukumnya. Sebab haramnya ialah karena keburukan-keburukannya, baik yang bersifat khusus maupun yang umum, dan juga karena membuat lalai dari mengingat Allah Swt. dan dari mengerjakan shalat serta menimbulkan permusuhan dan kebencian antara sesama manusia.

Pembuat syara' tidak membedakan antara minuman tersendiri dengan yang merupakan campuran dan juga tidak dibedakan antara minuman haram yang satu dengan minuman yang haram lainnya. Dan juga tidak membolehkan (sedikitnya) suatu minuman (haram), sementara mengharamkan (sedikitnya) suatu minuman (haram) lainnya. Tetapi semua sama (haramnya). Apabila yang sedikit dan minuman tersebut itu haram, maka begitu juga yang sedikit dan minuman haram lainnya.

\section{Jenis-jenis Khamar yang Terkenal}

Khamar atau minuman keras adalah zat yang paling sering disalahgunakan manusia, khamar atau minuman keras diperoleh atas peragian atau fermentasi madu, gula, sari buah atau umbi-umbian. Dari peragian tersebut dapat diperoleh khamar atau minuman keras sampai $15 \%$ tetapi dengan proses penyulingan (destilasi) dapat dihasilkan kadar khamar atau minuman keras yang lebih tinggi bahkan mencapai 100 \%. Kadar khamar atau minuman keras dalam darah maksimum dicapai 30 sampai 90 menit. Setelah diserap, khamar atau minuman keras disebarluaskan ke suluruh jaringan dan cairan tubuh. Dengan peningkatan kadar alkohol dalam darah orang akan menjadi euforia, namun dengan penurunannya orang tersebut menjadi depresi. 
Khamar atau minuman keras yang dijual di pasar-pasar itu bermacammacam namanya. Jenis tersebut terbagi atas beberapa bagian tertentu dengan patokan kadar alkohol yang terkandung di dalamnya. Ada yang bernama Brandy, Whisky, Martini, Liquor dan lain sebagainya. Kadar alkohol yang terkandung dalam minuman-minuman ini ada 40 sampai 60 \%. Kadar alkohol yang terdapat dalam Janever, Holand, dan Geneva adalah 33 sampai 40 \%. Jenis lain seperti Porte, Galagata, dan Madira mengandung 15 sampai 25 \% alkohol. Khamar-khamar ringan seperti Claret Hock, Champagne dan Bargendy mengandung 10 sampai $15 \%$ alkohol. Jenis-jenis bir ringan lainnya seperti Yet, Portar, Estote, dan Munich mengandung 2 sampai $9 \%$ alkohol. ${ }^{4}$ (Mutiara, 1985: 4-17). Ada lagi beberapa jenis lain yang mengandung alkohol sebanyak yang terkandung dalam jenis-jenis yang disebut terakhir ini. Misalnya Boozy, khamar yang terbuat dari perahan tebu dan lain-lain.

Lebih lanjut, ditemukan ada 3 golongan khamar atau minuman keras yang mengandung alkohol, yaitu golongan (A) kadar etanol 1 sampai 5 \% (Bir), golongan (B) kadar etanol 5 sampai 20 \% (Anggur atau Wine) dan golongan (C) kadar etanol 20 sampai 45 \% (Whiskey, Vodca, TKW, Manson House, Johny Walker, Kamput). ${ }^{5}$

Efek yang ditimbulkan setelah mengkonsumsi khamar atau minuman keras dapat dirasakan segera dalam waktu beberapa menit saja, tetapi efeknya berbeda-beda, tergantung dari jumlah atau kadar alkohol yang dikonsumsi. Dalam jumlah yang kecil, khamar atau minuman keras menimbulkan perasaan relax, dan pengguna akan lebih mudah mengekspresikan emosi, seperti rasa senang, rasa sedih dan kemarahan. Bila dikonsumsi berlebihan, akan muncul efek sebagai berikut: merasa lebih bebas lagi mengekspresikan diri, tanpa ada perasaan terhambat menjadi lebih emosional (sedih, senang, marah secara berlebihan) muncul akibat ke fungsi fisik motorik, yaitu bicara cadel,

\footnotetext{
${ }^{4}$ Mutiara, Majalah, (Jakarta: Sinar Harapan, 1985), hlm. 4-17

${ }^{5}$ Dadang Hawari, Penyalahgunaan Narkotika..., hlm. 21-23
} 
pandangan menjadi kabur, sempoyongan, inkoordinasi motorik dan bisa sampai tidak sadarkan diri. kemampuan mental mengalami hambatan, yaitu gangguan untuk memusatkan perhatian dan daya ingat terganggu.

Pengguna biasanya merasa dapat mengendalikan diri dan mengontrol tingkah lakunya. Pada kenyataannya mereka tidak mampu mengendalikan diri seperti yang mereka sangka mereka bisa. Oleh sebab itu banyak ditemukan kecelakaan mobil yang disebabkan karena mengendarai mobil dalam keadaan mabuk. Pemabuk atau pengguna alkohol yang berat dapat terancam masalah kesehatan yang serius seperti radang usus, penyakit liver, dan kerusakan otak. Kadang-kadang khamar atau minuman keras digunakan dengan kombinasi obat-obatan berbahaya lainnya, sehingga efeknya jadi berlipat ganda. Bila ini terjadi, efek keracunan dari penggunaan kombinasi akan lebih buruk lagi dan kemungkinan mengalami over dosis akan lebih besar.

\section{Pengharaman Khamar Secara Bertahap}

Umat Islam masih terus meminum khamar atau minuman keras hingga Rasulallah Saw. hijrah dari Mekah ke Madinah. Pada saat itu umat Islam bertanya-tanya tentang khamar atau minum keras dan tentang berjudi untuk melihat kejahatan-kejahatan dan kerusakan-kerusakan yang diakibatkan oleh kedua perbuatan itu. Oleh sebab itulah Allah Swt. menurunkan ayat sebagai berikut:

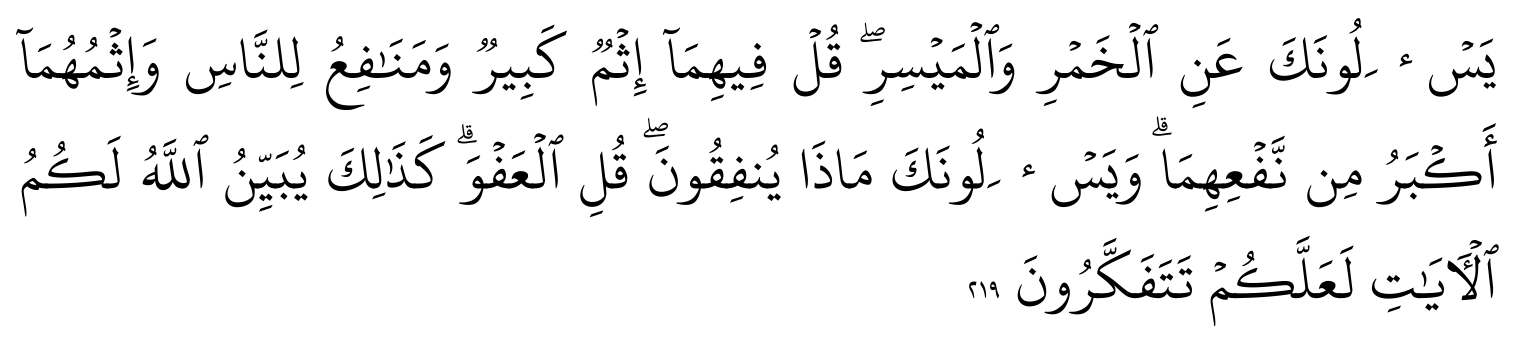

"Mereka bertanya kepadamu tentang khamar6 dan judi. Katakanlah: "Pada keduanya terdapat dosa yang besar dan beberapa manfaat bagi manusia, tetapi

${ }^{6}$ Segala minuman yang memabukkan adalah khamar. 
dosa keduanya lebih besar dari manfaatnya". dan mereka bertanya kepadamu apa yang mereka nafkahkan. Katakanlah: " yang lebih dari keperluan." Demikianlah Allah menerangkan ayat-ayat-Nya kepadamu supaya kamu berfikir". (Al-Baqarah ayat 219).

Maksud dari ayat di atas adalah bahwa melakukan kedua perbuatan itu mengandung dosa besar, karena di dalamnya terdapat kemudharatankemudharatan serta kerusakan-kerusakan materil dan keagamaan. Kedua hal tersebut memang mempunyai manfaat yang bersifat materil, yaitu keuntungan bagi penjual khamar atau munuman keras dan kemungkinan memperoleh harta benda tanpa usaha payah bagi si penjudi. Akan tetapi, dosanya jauh lebih banyak daripada manfaatnya. Lebih besar dosanya dari manfaat itulah yang menyebabkan keduanya diharamkan. Hal ini jugalah yang membuat keduanya lebih cenderung untuk diharamkan walaupun belum diharamkan secara mutlak.

Setelah ayat di atas turun, maka turun pula ayat yang mengharamkan khamar atau minuman keras dalam kaitannya dengan shalat (sambil meminumnya) terutama bagi mereka yang telah kecanduan khamar atau minuman keras dan menjadikannya sebagian dari hidupnya. Oleh sebab itulah turun ayat Al-Quran sebagai berikut:

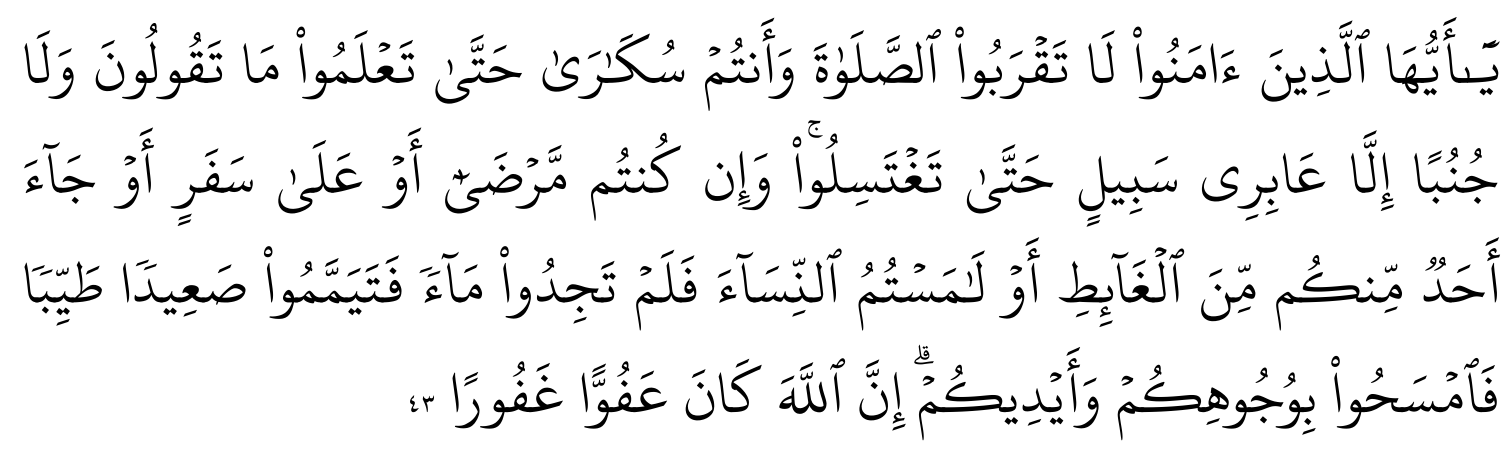

"Hai orang-orang yang beriman, janganlah kamu shalat, sedang kamu dalam Keadaan mabuk, sehingga kamu mengerti apa yang kamu ucapkan, (jangan pula 
hampiri mesjid) sedang kamu dalam Keadaan junub,7 terkecuali sekedar berlalu saja, hingga kamu mandi. dan jika kamu sakit atau sedang dalam musafir atau datang dari tempat buang air atau kamu telah menyentuh perempuan, kemudian kamu tidak mendapat air, Maka bertayamumlah kamu dengan tanah yang baik (suci); sapulah mukamu dan tanganmu. Sesungguhnya Allah Maha Pema'af lagi Maha Pengampun". (Al-Nisa' ayat 43).

Sebab turunya ayat ini adalah karena kasus seorang muslim yang mengerjakan shalat pedahal dia dalam keadaan mabuk, sehingga dia mengucapkan "قل يا ايهاالكفرون - اعبد ماتعبدون" tanpa menyebut huruf "لان".

Kasus ini merupakan pengantar bagi diharamkannya minum khamar atau minuman keras itu secara final dan setelah itu juga Allah Swt. mengharamkannya secara tuntas melalui ayat Al-Quran sebagai berikut:

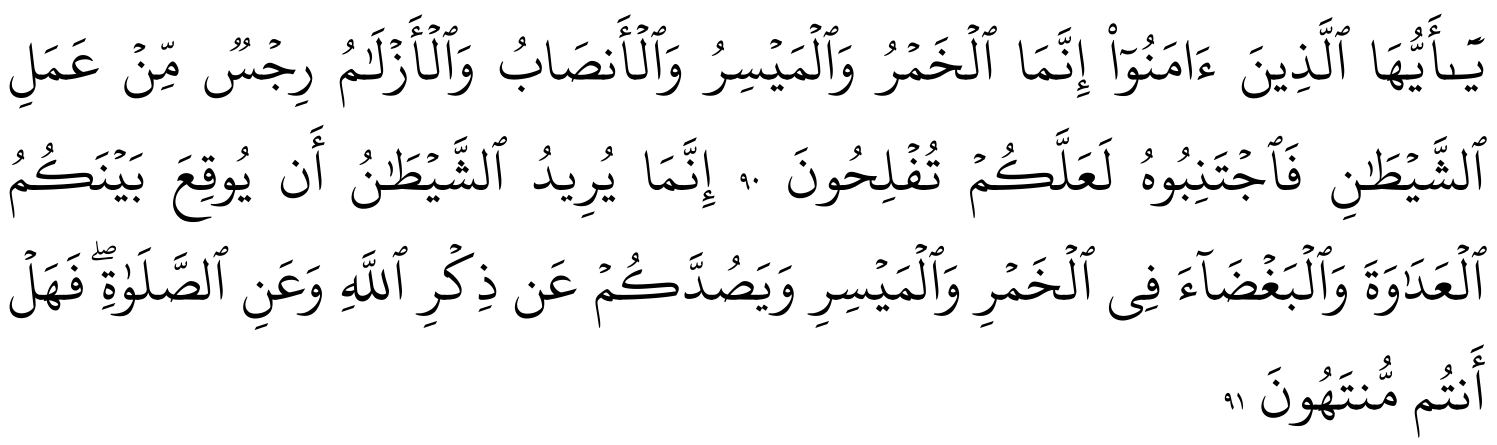

"Hai orang-orang yang beriman, Sesungguhnya (meminum) khamar, berjudi, (berkorban untuk) berhala, mengundi nasib dengan panah, 8 adalah Termasuk perbuatan syaitan. Maka jauhilah perbuatan-perbuatan itu agar kamu mendapat keberuntungan".

\footnotetext{
${ }^{7}$ Menurut sebahagian ahli tafsir dalam ayat ini termuat juga larangan untuk bersembahyang bagi orang junub yang belum mandi.

8 Al-Azlaam artinya: anak panah yang belum pakai bulu. orang Arab Jahiliyah menggunakan anak panah yang belum pakai bulu untuk menentukan Apakah mereka akan melakukan suatu perbuatan atau tidak. Caranya Ialah: mereka ambil tiga buah anak panah yang belum pakai bulu. setelah ditulis masing-masing Yaitu dengan: lakukanlah, jangan lakukan, sedang yang ketiga tidak ditulis apa-apa, diletakkan dalam sebuah tempat dan disimpan dalam Ka'bah. bila mereka hendak melakukan sesuatu Maka mereka meminta supaya juru kunci ka'bah mengambil sebuah anak panah itu. Terserahlah nanti Apakah mereka akan melakukan atau tidak melakukan sesuatu, sesuai dengan tulisan anak panah yang diambil itu. kalau yang terambil anak panah yang tidak ada tulisannya, Maka undian diulang sekali lagi.
} 
"Sesungguhnya syaitan itu bermaksud hendak menimbulkan permusuhan dan kebencian di antara kamu lantaran (meminum) khamar dan berjudi itu, dan menghalangi kamu dari mengingat Allah dan sembahyang; Maka berhentilah kamu (dari mengerjakan pekerjaan itu)". (Al-Maidah ayat 90-91).

Dari larangan di atas jelaslah bahwa Allah Swt. mengkatagorikan judi, berkorban untuk berhala dan bertenung (mengundi nasib) sama dengan khamar atau minuman keras. Oleh Allah Swt. semua hal tersebut dihukumkan sebagai berikut:

1. Keji dan menjijikkan, sehingga harus dihindari oleh setiap orang yang mempunyai pikiran bersih (waras).

2. Perbuatan godaan dan tipu daya setan.

3. Lantaran perbuatan itu perbuatan setan, maka haruslah dihindari. Dengan menjaukan diri dari perbuatan itu, maka berarti yang bersangkutan telah bersikap sedia untuk meraih kebahagiaan dan keberuntungan.

4. Tujuan setan mengoda manusia dengan minum khamar atau minuman keras dan judi tidak lain untuk merangsang timbulnya permusuhan dan persengketaan. Permusuhan dan persengketaan ini merupakan dua bentuk kerusakan duniawi.

5. Tujuan lain dari godaan itu adalah untuk menghalangi orang dari mengingat Allah Swt. dan melalaikan shalat. Hal ini jelas merupakan kerusakan terhadap keagamaan.

6. Atas dasar itulah manusia menghentikan perbuatan-perbuatan tersebut. Ayat di atas merupakan ayat terakhir yang menghukumi khamar atau minuman keras dengan hukum "haram mutlak" (qat'i).

Dari hal-hal tersebut itulah Allah Swt. memerintahkan kepada manusia agar tidak terperangkap dari berbagai macam tipu muslihat setan yang diberikan kepada manusia. Larangan ini juga merupakan ujian keimanan bagi seseorang, apakah ia mampu untuk menghadapinya atau sebaliknya. 


\section{E. Islam Melarang Keras Khamar}

Diharamkannya khamar atau minuman keras adalah sesuai dengan ajaran-ajaran Islam yang menginginkan terbentuknya pribadi-pribadi yang memiliki kekuatan fisik, jiwa dan akal pikirannya. Tidak diragukan lagi bahwa khamar atau minuman keras dapat melemahkan kepribadian dan menghilangkan potensi-potensinya terutama sekali akal. Seorang penyair mengatakan sebagai berikut:

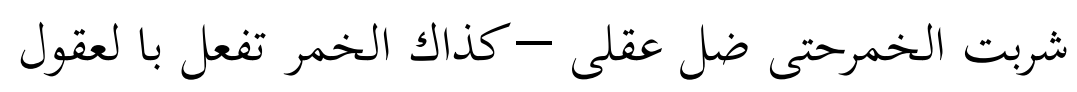

"Telah kuminum khamar dan sesatlah aku - Begitulah pengaruh khamar terhadap akal".

Luruskah apabila akal seseorang telah hilang, maka ia berubah menjadi binatang yang jahat dan timbul juga darinya kejahatan serta kerusakan yang tak terelakkan. Pembunuhan, permusuhan, membuka rahasia dan penghianatan terhadap tanah air adalah beberapa bentuk pengaruh negatif khamar.

Kejahatan-kejahatan ini tidak saja menyangkut diri si peminum khamar, tetapi lebih dari itu juga mempengaruhi teman-teman, tetangga dan orangorang yang sudah mempunyai kecenderungan ke arah itu. Sayidina Ali Ra. pernah menceritakan sewaktu ia bersama pamannya Hamzah, beliau memiliki dua ekor unta yang telah tua, kemudian ia mengumpulkan pohon izkhir (pohon yang harum baunya) bersama seorang Yahudi yang bekerja sebagai tukang emas untuk diangkut dengan untanya kemudian untuk dijual kepada tukang-tukang emas yang ada. Hasil penjualan pohon tersebut akan digunakan untuk membiayai perayaan pernikahan (walimah) Fatimah Ra. Waktu Hamzah meminum khamar bersama-sama dengan beberapa orang Anshar dan di antara mereka terdapat seorang biduanita. Sang biduanita kemudian menyenandungkan syair yang ternyata merangsang Hamzah untuk 
menyembelih untanya. Dipilihnya salah satu unta yang gemuk lalu disembelihnya dan diambillah hatinya.

Melihat kejadian itu Ali Ra. merasa jijik dan tidak sanggup menyaksikannya sehingga ia mengadu kepada Rasulallah Saw. Mendengar itu Rasulallah Saw. segera mendatangi Hamzah bersama-sama dengan Ali Ra. sendiri dan Zaid bin Haritsah. Beliau berang dan mencela perbuatan pamannya itu. Pada waktu itu Hamzah sedang dalam keadaan mabuk dan matanya menjadi merah. Ia memandang kepada Rasulallah Saw. dan orang-orang yang ada bersamanya seraya berkata "Kamu semua tidak lebih dari budak ayahku". Setelah mengetahui Hamzah sedang mabuk dan situasinya membahayakan, maka beliau bersama-sama sahabat yang lain segera pergi meninggalkan tempat tersebut. Begitulah akibat mengkonsumsi khamar, merusak dan menghilangkan kesadaran orang yang meminumnya. ${ }^{9}$

\section{F. Upaya Pencegahan Penyalahgunaan Khamar}

Dalam rangka untuk melakukan pencegahan terhadap penyalahgunaan khamar dan narkoba tersebut, paling tidak ada dua hal yang akan kami kemukakan untuk dijadikan solusi terhadap hal tersebut, yaitu:

1. Membangun Kehidupan Iman

Sebelum terkena khamar dan narkoba, individu sejak awal dapat disarankan agar membangun "benteng" pertahanan yang kuat sehingga mampu menjaga diri untuk tidak terpengaruh lingkungan yang tidak sehat. Artinya, ia mampu memilih lingkungan pergaulan yang sehat, yaitu mampu memilih teman yang baik bukan pecandu. Kalau bergaul dengan pecandu pun, ia tetap memiliki pendirian dan prinsip yang

${ }^{9}$ Lebih jelas lihat M. Ali Al-Shabuni (b), Rawai' Al-Bayan Tafsir Ayat Al-Ahkam, (Mekkah: tp., tt), hlm. 274. 
teguh, tidak goyah, dan tidak mudah ikut arus. Salah satu cara yang paling efektif adalah memperkuat iman. ${ }^{10}$

Individu sesuai dengan agama atau keyakinan yang dianutnya, diharapkan sungguh-sungguh menjalankan ajaran-ajaran dan perintah agama dengan baik. dengan demikian, tak perlu lagi orang tua mengkhawatirkan atau mencemaskan anak-anak yang beriman kokoh tersebut. Untuk itu, orang tua pun perlu membimbing, membina dan mengarahkan kehidupan agama anaknya sejak dini, jangan sampai mereka terkena yang namanya khamar dan narkoba tersebut.

Karena itu, yang terbaik adalah orang tua sendirilah yang menjadi model pertama, yaitu mereka harus sungguh-sungguh menjalankan agama atau keyakinan yang dianutnya dengan baik. melihat lingkungan keluarga yang baik itu, anakpun akan meniru orang tuanya. Sebaliknya, kalau model kehidupan orang tua kurang baik (amburadul), anaknya pun cenderung berperilaku rusak. Oleh karena itu, sebelum mengajari dan membimbing anak, orang tua harus menjadi contoh yang baik terlebih dahulu. Karena contoh tindakan nyata yang baik akan menjadi efektif untuk mendidik anaknya sehingga tidak terpengaruh dalam penyalahgunaan khamar dan narkoba.

2. Memberikan Pelatihan-Pelatihan Keterampilan Psikososial

Seorang remaja yang belum berpengalaman dalam pergaulan akan memiliki taraf kerentanan yang tinggi, artinya ia akan mudah dipengaruhi oleh lingkungan sosial. Banyak godaan ataupun tawarantawaran dari luar dirinya yang cenderung membawa pengaruh negatif dan destruktif, misalnya ajakan untuk mencoba khamar dan narkoba. ${ }^{11}$

10 Agoes Dariyo, Psikologi Perkembangan Dewasa Muda, (Jakarta: PT. Gramedia Widiasarana Indonesia, 2003), hlm. 35.

${ }^{11}$ Suryabrata, Psikologi Kepribadian, (Jakarta: Rajawali Press, 1993), hlm. 43. 
Ketidakmampuan untuk menangkal atau mencegahnya akan menyebabkan dirinya memiliki kebiasaan atau perilaku yang buruk (meyimpang) dari norma sosial. Oleh karena itu, sejak dini, sebelum terlambat, sebaiknya seorang remaja sebaiknya memperoleh pelatihan untuk memahami bahaya penyalahgunaan khamar dan narkoba. Pelatihan ini diharapkan untuk meningkatkan kemampuan bersikap asertif (assertivity training) dengan mengatakan "Tidak" terhadap tawaran penggunaan khamar dan narkoba, pelatihan peningkatan rasa percaya diri dan harga diri bagi remaja yang mengalami masalah kepribadian ini.

Adapun solusi yang diberikan oleh pemerintah terhadap penyalahgunaan khamar dan narkoba ini adalah melalui sanksi pidana. Adapun landasan hukumnya mengenai zat psikoaktif ini di atur dalam Undang-undang No. 5 Tahun 1997 tentang Psikotropika dan Undang-undang No. 22 Tahun 1997 tentang Narkotika. ${ }^{12}$

Karena itu, usaha untuk menanggulanginya sangat penting (preventif promotif). Seluruh lapisan masyarakat perlu diberi tahu mengenai zat, akibatakibat, dan cara penanggulangannya. Selain itu, perlu upaya kuratif dan rehabilitasi, yaitu berusaha untuk mengakhiri ketergantungan zat psikoaktif, mengatasi dampak fisik, psikis, dan sosial. Selain itu juga, mengembalikan mereka ke dalam lingkungan masyarakat agar menjadi warga yang produktif, berguna dan hidup sejahtera.

\section{G. Pengobatan Dengan Khamar}

Sebelum lahirnya agama Islam, masyarakat Jahiliyah telah meminum khamar untuk maksud pengobatan. Islam datang melarang mereka tersebut.

12 Supaya lebih jelas lihat kembali penjelasan pasal-pasal dalam Undang-undang 
menggunakan khamar untuk berobat dan mengharamkannya juga. Dalam hal ini imam Ahmad, Muslim, Abu Dawud dan Tirmidzi meriwayatkan dari Thariq bin Suwaid al-Ju'fi sebagai berikut:

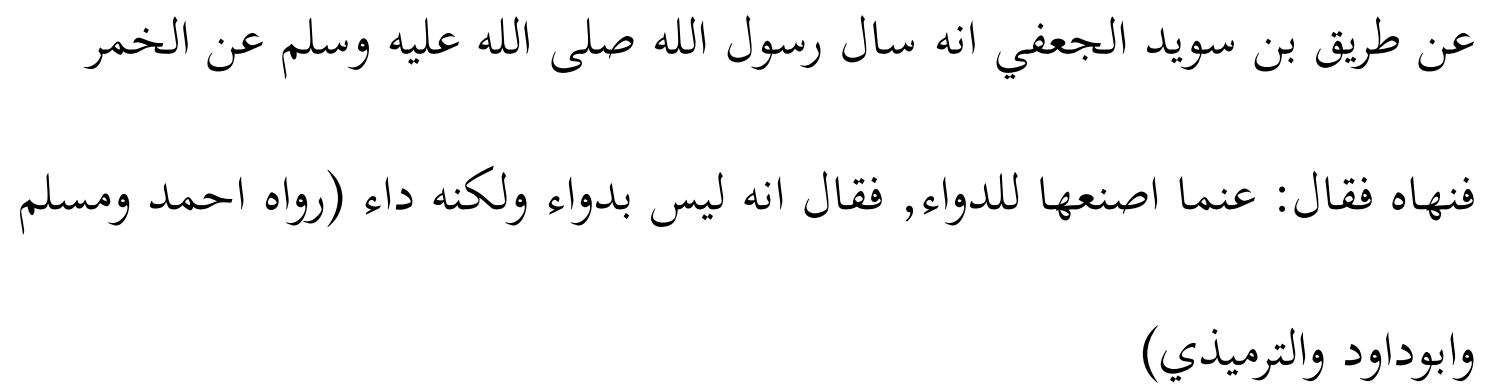

"Beliau ini pernah bertanya kepada Rasulallah Saw. tentang khamar, Rasulallah Saw. melarangnya, lalu Suwaid berkata, "saya buat khamar itu hanya untuk obat". Rasulallah Saw. menjawab, khamar itu bukannya obat, tetapi justru penyakit".

Dalam riwayat yang lain Abu Dawud meriwayatkan dari Abu Darda bahwa Rasulallah Saw. pernah bersabda sebagai berikut:

$$
\begin{aligned}
& \text { عن ابي الدرد اء ان النبي صلى الله عليه وسلم قال: ان الله انزل الد اءوالدواء وجعل } \\
& \text { لكل د اء دواء فتداووا ولاتداووا بحرام (رواه ابود اود) }
\end{aligned}
$$

"Sesungguhnya Allah Swt. telah menurunkan penyakit beserta obatnya. Oleh karenanya berobatlah kamu tetapi jangan dengan barang yang haram".

Pada masa sebelum Islam, orang-orang Jahiliyah sering juga menggunakan khamar itu untuk mengatasi dinginnya cuaca. Tetapi hal inipun dilarang oleh Islam.

Akan tetapi, sebagian ahli ilmu membolehkan pengobatan dengan khamar dengan syarat tidak ada obat lain yang halal untuk menggantikan obat yang haram itu (khamar). Kemudian disyaratkan orang yang berobat tersebut tidak bermaksud untuk kesenangan dan tidak ingin kelezatan serta tidak juga melebihi ukuran yang ditentukan oleh dokter. Hal ini disamakan dengan 
bolehnya menggunakan khamar apabila dalam keadaan darurat. Hal ini sejalan dengan qaidah hukum sebagai berikut:

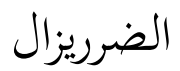

"Kemudharatan harus dihilangkan". ${ }^{13}$

Menurut qaidah di atas, darurat adalah kesulitan yang menentukan eksistensi manusia, karena jika ia tidak diselesaikan akan mengancam agama, jiwa, nasab harta serta kehormatan manusia, oleh sebab itu dalam keadaan ini khamar diperbolehkan.

\section{H. Analisis Terhadap Persoalan}

Pada dasarnya, hadits-hadits yang berbicara tentang khamar dapat dibagi menjadi dua kelompok besar, sedangkan yang lain tersubordinasi dalam hadits yang lain. Adapun kelompok tersebut adalah sebagai berikut:

1. Hadits yang menunjukkan keharaman khamar dari sisi dzatnya, hal ini sebagaimana pengharaman daging babi.

2. Hadits yang menunjukkan keharaman khamar dari sisi sifatnya (ada illat).

Kelompok hadits Pertama, keharaman khamar karena dzatnya sendiri, bukan karena sifatnya. Adapun hadits yang termasuk dalam kelompok ini cukup banyak, misalnya: Abu Aun al-Tsaqafi meriwayatkan hadits dari Abdullah bin Syaddad dan Ibnu Abbas bahwa Rasulallah Saw. bersabda:

"Khamar itu diharamkan karena bendanya itu sendiri, sedangkan (diharamkan) mabuknya itu adalah karena hal lain".

13 Al-Suyuthi, Jalaluddin Abdurrahman, al-Asyba' Wan Nadhoir, (Indonesia: Syirkah Nur Asia, t.t), hlm. 59, Lihat juga Muchlis Usman, Kaidah-Kaidah Ushuliyah dan Fighiyah Pedoman Dasar Dalam Istinbath Hukum Islam, (Jakarta: Rajawali Press, 2001), hlm. 132. 
Nash ini tidak memerlukan takwil lagi bahwa khamar diharamkan karena dzatnya bukan karena sifat memabukkannya. Dalam kitab Bidayatul alMujtahid, Ibnu Rusyd menyatakan, bahwa para ulama sepakat bolehnya minum khamar yang berubah menjadi cuka. Ini didasarkan pada hadits yang dikeluarkan oleh Imam Abu Dawud dari Anas bin Malik yang menceritakan bahwa Abu Thalhah bertanya kepada Rasulallah Saw. tentang anak-anak yatim yang mendapatkan warisan khamar. Rasulullah Saw bersabda:

"Tumpahkanlah khamar itu. Abu Thalhah bertanya lebih lanjut, Apakah tidak boleh aku olah menjadi cuka? Rasulallah Saw. berkata lagi, Jangan".

Hadits ini juga dikeluarkan oleh Imam Muslim dan Al-Tirmidzi. Hadits ini hanya menunjukkan larangan untuk mengolah khamar menjadi cuka. Akan tetapi bila khamar sudah berubah menjadi cuka, dibolehkan untuk diminum. Khamar yang berubah menjadi cuka tentu bukan khamar yang bermakna semua sifat yang memabukkan. Sebab, candu, ganja, opium dan lain-lain tidak bisa berubah menjadi cuka. Ini menunjukkan bahwa khamar adalah benda tersendiri. Dalam penelitian modern menunjukkan bahwa etanol (substansi dari khamar) memang bisa berubah menjadi cuka (asam asetat).

Diriwayatkan dari Ali Ra., bahwa Rasulallah Saw. telah melarang mereka minum perahan biji gandum (bir).

Dalam Al-Sunan terdapat hadits yang diriwayatkan dari Nu'man bin Basyir, bahwa Rasulallah Saw. bersabda:

"Sesungguhnya dari anggur itu bisa dibuat khamar, dan dari kurma itu bisa dibuat khamar, dari madu itu bisa dibuat khamar, dari gandum itu bisa dibuatkhamar dan dari biji syair itupun bisa dibuat khamar".

Imam Bukhari dan Muslim meriwayatkan bahwa Umar bin Khatab pernah berpidato sebagai berikut, "Amma $b a^{\prime} d u$. Wahai manusia! Sesungguhnya telah diturunkan hukum yang mengharamkan khamar. Ia terbuat dari salah satu dari lima unsur; anggur, korma, madu, jagung, dan gandum. Khamer 
adalah sesuatu yang mengacaukan akal. dan lain sebagainya". Hadits-hadits ini seluruh berbicara pada konteks pengharaman khamer dari sisi dzatnya, bukan sifatnya. Ini menunjukkan bahwa khamar adalah dzat tersendiri yang memiliki sifat menonjol, yakni memabukkan dan mengacaukan akal.

Sedangkan kelompok hadits Kedua, khamar diharamkan karena sifatnya yang memabukkan dan mengacaukan akal. Adapun hadits-hadits yang menyatakan katagori khamar diharamkan karena sifatnya yang memabukkan adalah sebagai berikut:

1. "Khamar adalah sesuatu yang mengacaukan akal. (HR. Bukhari dan Muslim).

2. "Setiap yang memabukkan adalah haram. Allah Swt. berjanji kepada orangorang yang meminum minuman yang memabukkan, bahwa Dia akan memberi mereka minuman dari thinah al-khabal. Ia bertanya, Apa itu thinah al-khabal ya Rasulallah Saw.? Rasulullah Saw. menjawab, Keringat ahli-ahli neraka atau perasan tubuh ahli neraka". (HR. Muslim).

3. "Dari Ibnu Umar dari Aisyah bahwa Rasulallah Saw. bersabda: Setiap yang memabukkan adalah khamar dan setiap khamar adalah haram". (HR. Muslim). ${ }^{14}$

4. "Minuman yang banyaknya memabukkan, maka sedikitnya juga diharamkan". (HR. Tirmidzi).

Hadits-hadits tersebut di atas mengesankan bahwa khamar yang dilarang oleh syariat Islam adalah semua minuman yang memabukkan dan mengacaukan akalnya. Dengan kata lain, jika suatu produk mengandung sifat atau memiliki potensi memabukkan, maka produk itu terkategori sebagai khamar. Dari kelompok hadits ini, kita bisa menyimpulkan bahwa, gadung, kecubung, ganja, morpin termasuk khamar, karena sifatnya yang memabukkan. hlm. 100

${ }^{14}$ Abi Al-Khusain Muslim bin Hajjad, Shahih Muslim, Juz III, (Beirut: Dar Al-Fikr, tt), 
Jika dua kelompok hadits tersebut dipahami secara sepihak, tentunya kesimpulannya tidak akan utuh dan sempurna. Bahkan, tindakan berdalil secara sepihak, dengan mengesampingkan hadits-hadits yang lain, termasuk perbuatan mengabaikan sabda Rasulallah Saw. dan hal ini adalah perbuatan haram. Oleh karena itu, diperlukan istinbath shahih untuk menggabungkan keseluruhan dalil-dalil tersebut, agar tidak satupun hadits yang terlantar atau terabaikan; dan agar kita bisa memahami secara sempurna apa yang dimaksud Rasulallah Saw. dengan khamar. Jika kita teliti secara jernih dan mendalam dua kelompok hadits di atas, kita bisa mengetengahkan sebuah kompromi sebagai berikut:

Pertama, yang dimaksud oleh syara dengan khamar yang dilarang untuk dikonsumsi adalah substansi dari sebuah benda tertentu, bukan sekumpulan benda yang membentuk makanan atau minuman tertentu, yakni sesuatu benda apabila dikonsumsi akan menutupi akal atau memabukkan, sehingga hal tersebut yang menyebabkan makanan atau minuman haram untuk dimakan. Akan tetapi, khamar adalah substansi dari sebuah benda. Ini didasarkan pada sebuah hadits dari Abu 'Aun Al-Tsaqafi dari Abdullah bin Syaddad dan Ibnu Abbas bahwa Rasulallah Saw. bersabda:

"Khamar itu diharamkan karena bendanya itu sendiri, sedangkan (diharamkan) mabuknya itu adalah karena hal lain".

Adapun hadits-hadits yang berada pada kelompok kedua, harus dipahami bahwa memabukkan atau mengacaukan akal merupakan dampak lain dari meminum khamar. Tidak boleh dipahami, bahwa memabukkan dan mengacaukan akal adalah illat atau sebab diharamkannya khamar. Sebab, hadits-hadits kelompok kedua sama sekali tidak mengandung illat, baik yang ditunjukkan secara shurahah (jelas), dengan huruf-huruf illat, dilalah, istinbath, maupun qiyas. Oleh karena itu, memabukkan atau mengacaukan akal bukanlah illat pengharaman khamar, dan ia tidak boleh ditetapkan sebagai illat. Selain itu, jika memabukkan dan mengacaukan akal adalah illat dari pelarangan 
khamar, tentunya hukumnya keharaman khamar tidak berlaku bagi mereka yang tidak mabuk dan kacau akalnya jika mengkonsumsi khamar. Sebab, kaedah ushul fiqh tentang illat adalah, al-illatu tadîru ma'a ma'lîl wujûdan wa adaman (illat itu beredar bersama hukum ada atau tidak adanya). Jika penyebab pelarangan khamar, yakni memabukkan dan mengacaukan akal sehingga menjadi lenyap, maka keharamannya juga akan lenyap. Pedahal, banyak orang minum khamar tapi tidak mabuk.

Oleh karena itu, berapapun kadar khamar (etanol) yang diminum, maka hukumnya tetap haram. Pengharaman ini didasarkan pada dzatnya, bukan karena kuantitasnya. Adapun hadits yang diriwayatkan oleh Imam al-Tirmidzi dan al-Nasa'i yang menyatakan, "Minuman yang banyaknya memabukkan, maka sedikitnya juga diharamkan", hanya menegaskan keharaman khamar, bukan menunjukkan kuantitas khamar yang diharamkan. Artinya, berapapun kuantitas khamar yang diminum maka ia tetap haram. Jika tidak dipahami demikian, tentunya minuman yang diminum dengan kuantitas yang banyak dan memabukkan, maka sedikitnya pun, walau tidak memabukkan adalah haram. Pemahaman semacam ini akan membawa konsekuensi, bahwa gadung, (sejenis umbian), kecubung, dan lain-lain yang jelas-jelas halalnya, akan berubah menjadi haram. Sebab, jika gadung dan lain-lain ini dikonsumsi dalam jumlah yang banyak ia akan memabukkan; namun tidak berarti sedikitnya juga haram, hal ini sesuai dengan hadits yang diriwayatkan oleh al-Tirmidzi dan alNasa'i di atas.

Kedua; adapun hadits yang berbicara mengenai juice yang berubah menjadi khamar selama lebih dari dua hari, sesungguhnya hadits ini pun tidak membatasi pelarangan khamar pada kadar tertentu, maupuan pelarangan khamar berdasarkan tenggang waktu pembuatannya. Hadits ini harus dipahami, bahwa juice yang telah terfermentasi menjadi etanol (khamar) berapapun kadarnya dan dalam tenggang waktu berapapun, maka juice itu telah berubah menjadi khamar. Adapun tenggang waktu dua hari yang 
dilakukan oleh Rasulallah Saw. sesungguhnya ini hanyalah tahqiq al-manath Rasulallah Saw. mengenai khamar. Karena teknologi saat itu masih sangat sederhana, maka untuk mengenali khamar diperlukan suatu identifikasi yang bisa membuktikan (meskipun dengan dugaan kuat) bahwa juice itu telah mengandung etanol. Dan harus kita maklumi, bahwa etanol baru bisa diidentifikasi oleh Rasulallah Saw. setelah juice itu diperam selama lebih dari 2 hari atau setelah keluar gasnya; sebab, identifikasi yang dilakukan Rasulallah Saw. masih bersifat manual (dicium baunya, keluar gasnya, atau dilihat penampilan).

Wajar saja, jika saat itu ditetapkan tenggang waktu perubahan juice menjadi khamar selama 2 hari. Jadi, hadits itu tidak membatasi secara mutlak bolehnya minum juice sebelum hari ketiga, dan setelah itu tidak boleh; dengan alasan setelah hari ketiga kadar etanolnya telah cukup banyak. Akan tetapi, hadits itu hanya menunjukkan perkiraan atau identifikasi Rasulallah Saw. mengenai munculnya etanol. Oleh karena itu, secara hukum, waktu 2 hari itu bukanlah taqyid, akan tetapi sekedar menunjukkan tahqiq, tidak lebih. Jika ada tahqiq al-manath yang lebih cermat, dan bisa dibuktikan dengan jalan penginderaan langsung atau tidak langsung, maka tahqiq yang cemerlang itu harus lebih diikuti. Ini berarti, jika identifikasi modern lebih cermat dibandingkan dengan identifikasi Rasulallah Saw. tentunya kita harus mengikuti tahqiq yang lebih cemerlang.

Jadi walaupun pemeraman masih berjalan satu hari, akan tetapi bila di dalamnya sudah teridentifikasi etanol dalam kadar berapapun, tentunya minuman itu tidak boleh dikonsumsi lagi. Masalah ini, seperti halnya dengan ketidaktepatan Rasulallah Saw. dalam menetapkan tempat bertahan dalam perang Badar, atau ketidaktepatan Rasulallah Saw. dalam kasus penyerbukkan kurma. Pada kasus perang Badar, tahqiq (identifikasi) Rasulallah Saw. dikritik oleh Khubaib bin Mundzir. Sebab, menurut Khubaib ketetapan Rasulallah Saw. itu tidak tepat, dan akhirnya Rasulallah Saw. mengikuti identifikasi Khubaib. 
Demikian juga tatkala Rasulallah Saw. menyarankan petani kurma untuk tidak menyerbuki kurmanya, ternyata hasilnya tidak memadai. Lantas, kejadian itu disampaikan kepada Rasulallah Saw. dan Rasulallah Saw. berkata, "kamu lebih memahami urusan kalian".

Oleh karena itu, hadits yang berbicara tentang juice yang diperam selama 3 hari, atau setelah keluar gasnya, sama sekali tidak menunjukkan taqyid hukum, akan tetapi hanya menunjukkan identifikasi yang dilakukan oleh Rasulallah Saw. Sedangkan identifikasi Rasulallah Saw. bisa jadi kurang tepat, atau kurang valid. Lantas, bolehkah kita mengkritik identifikasi Rasulallah Saw. dalam masalah ini? Jawabnya boleh. Sebab, dalam urusan seperti ini Rasulallah Saw. memang tidak maksum, alias bisa jadi tidak tepat; seperti halnya kasus penyerbukan kurma, dan pertahanan di Perang Badar. Oleh karena itu, pelarangan khamar itu dikarenakan dzatnya itu sendiri, dan sama sekali tidak berhubungan dengan kuantitas dan kadarnya, maupun tenggang waktu pembuatannya.

Ketiga, di sisi yang lain, ada hadits-hadits dari Rasulallah Saw. yang mengharamkan juice tanpa disertai dengan tenggang waktu. Diriwayatkan dari Ali Ra., bahwa Rasulallah Saw. telah melarang mereka minum perahan biji gandum. Bukti lain yang mengukuhkan bahwa yang dimaksud khamar adalah etanol, adalah hadits yang berbicara perubahan khamar menjadi cuka. Hadits ini menunjukkan dengan sangat jelas bahwa yang dimaksud khamar adalah alkohol (etanol). Sebab, hanya alkohol yang bisa berubah menjadi cuka dalam kondisi biasa. Keterangan ini juga membantah pendapat sebagian pakar yang menyatakan bahwa yang dimaksud khamar adalah sekumpulan dzat yang satu sama lain memiliki sifat memabukkan, bukan etanolnya saja.

Keterangan ini akan bertabrakan dengan fakta perubahan khamar menjadi cuka. Jika, yang dimaksud khamar adalah sekumpulan benda yang membentuk khamar, lantas pertanyaannya, apakah sekumpulan benda itu 
berubah semuanya menjadi cuka, ataukah etanolnya saja. Jawabnya, pasti cuka terbentuk dari etanolnya, bukan sekumpulan benda-benda itu tadi.

Keempat, bahwa yang disebut khamar bukanlah etanol saja, akan tetapi sekumpulan benda (seandainya mengikuti penjelasan penulis ratusan senyawa kimia). Etanol adalah salah satu komponen pendukung saja. Ia juga beralasan, bahwa tak seorangpun sanggup mengkonsumsi etanol murni; sebab mematikan. Lantas, dapat disimpulan bahwa etanol bukanlah khamar, jadi etanol tetap berhukum mubah, karena berlaku hukum tentang benda.

Akan tetapi perlu ditegaskan lagi, bahwa keberadaan etanol murni yang bersifat toxic (mematikan) jika dikonsumsi, tidak menafikan keberadaannya sebagai khamar. Sebab, semua orang tahu baik awam atau tidak, bahwa yang disebut minuman keras adalah minuman yang ditambahi etanol dengan kadar tertentu. Jika kita mengikuti beberapa pendapat pakar, berarti, hukum etanol mubah, sehingga ditambahkan dalam kadar berapapun dalam sebuah minuman, maka minuman harusnya tetap halal. Sebab, benda yang dihukumi halal berdasarkan dzatnya, selamanya tetap halal, kecuali jika ada sebab-sebab syar' $i$, misalnya mengandung bahaya, atau diperoleh dengan cara yang haram (mencuri dan sebagainya).

Kelima, jika yang dimaksud khamar itu adalah sekumpulan dzat (air, glukosa, ragi (yeast), karbondioksida, dan sebagainya sampai 100 senyawa), tentunya jika salah satu komponen itu tidak ada, maka dzat itu tidak lagi disebut khamar. Ini berkonsekuensi bahwa khamar yang dilarang hanyalah khamar yang dibuat di jaman Rasulallah Saw. saja. Sebab, banyak pembuatan khamar di jaman modern yang secara struktur maupun kandungan dzat jelasjelas berbeda dengan khamar di masa Rasulallah Saw. Padahal, semua orang sudah tahu, bahwa minuman greensand yang beralkohol 5\% tetap disebut khamar dan diharamkan.

Pada dasarnya, sebuah hukum hanya berlaku untuk sebuah kasus dan benda saja. Hukum yang berlaku atas sebuah benda, tidak bisa dianalogkan 
atau diterapkan pada benda lain yang berbeda senyawa dan strukturnya. Jika benda atau sekumpulan bendanya berbeda tentu saja hukum itu tidak bisa diterapkan. Padahal, di atas telah dinyatakan, bahwa khamar bisa dibuat dari bahan apapun, tidak harus seperti yang dicontohkan pada masa Rasulallah Saw.

Keenam, adapun mengenai metanol, propanol, kloroform dan sebagainya yang memiliki potensi toxic, sesungguhnya benda-benda ini, adalah halal pada asalnya. Sebab, tidak ada satupun dalil yang mengharamkannya; sehingga berlaku kaedah hukum asal benda yakni mubah. Oleh karena itu, ia boleh digunakan dalam konteks apapun, selain dikonsumsi. Keharaman untuk dikonsumsi didasarkan sabda Rasulallah Saw. "Tidak ada bahaya dan membahayakan di dalam Islam", hal ini bukan dikarenakan benda itu khamar. Sebab, benda-benda tersebut bukan khamar.

Pengharamannya didasarkan pada adanya bahaya. Oleh karena itu, berlaku kaedah bagi benda, yaitu "Hukum asal benda adalah boleh selama tidak ada dalil yang mengharamkannya". Jadi benda apapun, baik beracun atau tidak, hukum asalnya adalah mubah (selain khamar). Hanya saja, jika benda itu beracun dan mematikan manusia. Sedangkan penggunaan benda tersebut untuk hal lain adalah mubah; misalnya untuk antiseptik atau strerilisasi alat-alat kedokteran.

Ketujuh, jika demikian, tentunya manusia akan kesulitan untuk meninggalkan praktek-praktek yang banyak melibatkan etanol. Jawabnya, seorang muslim mesti menjunjung tinggi syariat di atas keinginan, kepentingan, dan kemashlahatannya. Seorang muslim pantang mengeluarkan pernyataan seperti "Jika ini diharamkan tentunya akan menyulitkan kita". Sesungguhnya, saat ini sudah ditemukan pelarut-pelarut universal yang bisa menggantikan kedudukan etanol, sebagai pelarut universal. Selain itu, masih banyak alternatif bahan kimia yang bisa menggantikan peran etanol. Ini hanya masalah policy dari negara saja. Jika negaranya konsens dengan syariat tentu ia akan 
melindungi warganya dari perbuatan haram. Sayangnya, kita masih bingung, apakah negara kita negara muslim atau sekuler, dan pemimpinnya tidak care dengan syariat Islam.

Kedelapan, adapun anggapan yang menyatakan, bahwa ada bahan-bahan makanan tertentu, atau buah-buahan alami yang mengandung alkohol (etanol) dengan kadar sangat sedikit, tentunya makanan-makanan tersebut harusnya diharamkan karena mengandung khamar (etanol). Dalam bahan-bahan makanan alami, yang terdeteksi itu bukanlah etanol, akan tetapi gugus $\mathrm{OH}$-nya (alkohol). Sebab, struktur kimia dalam makanan-makanan alami, jeruk, roti, dan lain-lain, pasti bersifat kompleks, dan tidak menunjuk pada struktur yang bersifat tunggal

Semoga tanggapan ini, mampu membukakan pintu kebenaran dan menobrak kebodohan, dan mampu merevisi pemahaman yang kurang tepat (komprehensif).

\section{Kesimpulan}

Berdasarkan penjelasan di atas, maka dapat disimpulkan beberapa hal, yaitu sebagai berikut:

1. Pengertian khamar secara ekplisit tidak ditemukan karena yang dimaksud dengan khamar itu sendiri oleh Rasulallah Saw. tidak jelas, sehingga penulis berkesimpulan bahwasanya yang dimaksud khamar di sini adalah cairan yang dihasilkan dari peragian biji-bijian atau buah-buahan dan mengubah saripatinya menjadi alkohol dengan menggunakan katalisator (enzim) yang mempunyai kemampuan untuk memisahkan unsur-unsur tertentu yang berubah melalui proses peragian. Sehingga minuman sejenis ini dinamakan khamar karena ia mengeruhkan dan menyelubungi akal. Artinya menutupi dan merusak daya tangkapnya. 
Winarno

2. Untuk mengatasi penyalahgunaan khamar di kalangan generasi muda saat ini hendaknya dilakukan dengan membangun kehidupan iman dan memberikan pelatihan-pelatihan keterampilan psikososial.

3. Penggunaan khamar oleh medis boleh dilakukan apabila hal tersebut merupakan alternatif terakhir. Karena hal tersebut merupakan mudharat, dan kemudharatan dalam Islam harus dihilangkan. Hal ini mengingat agama Islam memerintahkan agar penganutnya untuk menjaga agama, jiwa, nasab, harta serta kehormatan manusia. Tegasnya penggunaan khamar oleh medis sangat kondisional. 


\section{DAFTAR PUSTAKA}

\section{Al-Quran Nul Karim}

Al-Shabuni, M. Ali. Terjemahan Tafsir Ayat Ahkam. Diterjemahkan Oleh: Mu'ammal Hamidy dan Imron Al-Manan, (Surabaya: PT. Bina Ilmu,tt) Rawai' Al-Bayan Tafsir Ayat Al-Ahkam, (Mekkah: tp,tt)

al-Suyuthi, Jalaluddin Abdurrahman, al-Asyba' Wan Nadhoir, (Indonesia: Syirkah Nur Asia, $\mathrm{tt}$ )

Dariyo, Agoes, Psikologi Perkembangan Dewasa Muda, (Jakarta: PT. Gramedia Widiasarana Indonesia, 2003)

Direktorat Kesehatan Jiwa Depkes, Pedoman Penggolongan dan Diagnosis Gangguan Jiwa di Indonesia Edisi II, (Jakarta: tp, 1983)

Hajjad, Abi Al-Khusain Muslim bin, Shahih Muslim. Juz III. (Beirut: Dar Al-Fikr,tt)

Hawari, Dadang, Penyalahgunaan Narkotika dan Zat Adiktif, (Jakarta: Balai Penerbit Fakultas Kedokteran Indonesia, 1991) Al-Quran, Ilmu Kedokteran Jiwa dan Ilmu Kesehatan Jiwa, (Jakarta: Dana Bhakti Prima Yasa, 1999)

, "Kelainan Paru dan Lever Pada Penderita Ketergantungan Narkotika Jenis Opiat". Terapi (Detoksifikasi) dan Rehabilitasi Pasien NAZA Edisi III, (Jakarta: Universitas Indonesia Press, 2000)

Mutiara, Majalah, (Jakarta: Sinar Harapan, 1985)

Sabiq, Sayyid, Figh Sunnah Jilid III, Alih Bahasa: Nor Hasanuddin, (Jakarta: Pena Pundi Aksara, 2004)

Suryabrata, Psikologi Kepribadian, (Jakarta: Rajawali Press, 1993)

Usman, Muchlis, Kaidah-Kaidah Ushuliyah dan Fiqhiyah Pedoman Dasar Dalam Istinbath Hukum Islam, (Jakarta: Rajawali Press, 2001) 